Journal of Applied Pharmaceutical Science Vol. 6 (11), pp. 105-113, November, 2016

Available online at http://www.japsonline.com

DOI: $10.7324 / \mathrm{JAPS} .2016 .601117$

ISSN 2231-3354 (cc) BY-NC-sa

\title{
Sub-chronic oral toxicity study of Kushta Hajrul-Yahood (A Herbo- mineral Unani formulation) in Wistar rats
}

\author{
Showkat A. Dar ${ }^{1,2^{*}}$, Seema Akbar ${ }^{1}$, Khalid Ghazanfar ${ }^{1}$, Mariya Hamdani ${ }^{1}$, Tazeen Nazir ${ }^{1}$, Masood S Mir ${ }^{3}$, Akbar \\ Masood $^{2}$, Humma Rafiq ${ }^{1}$, Showkat A Ganie ${ }^{2}$ \\ ${ }^{1}$ Regional Research Institute of Unani Medicine, Srinagar, J\&K, India. ${ }^{2}$ Department of Biochemistry, University of Kashmir, Srinagar, J\&K, India. \\ ${ }^{3}$ Sher-e-Kashmir University of Agriculture Science \& Technology-Kashmir, Shuhama Alustang, J\&K, India.
}

\begin{tabular}{l} 
ARTICLE INFO \\
\hline Article history: \\
Received on: $29 / 06 / 2016$ \\
Revised on: 04/08/2016 \\
Accepted on: $26 / 08 / 2016$ \\
Available online: $29 / 11 / 2016$ \\
\hline Key words: \\
Sub-chronic toxicity, Hajrul- \\
Yahood, biochemical \\
parameters, haematological \\
parameters, Histopathology.
\end{tabular}

\begin{abstract}
PD (Kushta Hajrul Yahood) is a Unani drug used for the treatment of renal and bladder calculi. The aim of the study was to demonstrate the scientific validity of detoxification method for preparation of Kushta and also to investigate the sub-chronic oral toxicity study of PD and CM (Crude material of Kushta Hajrul Yahood-its Undetoxified form) in Wistar rats. Animals were orally treated once daily with test substance at the dose level of $1000 \mathrm{mg}$ and its two sub fractions 500 and $250 \mathrm{mg} / \mathrm{kg}$ body weight for 90 -days. Rats were observed throughout the study period. Body weight, feed and water consumption were recorded weekly. Overnight fasted rats were sacrificed on $91^{\text {st }}$ day. Blood sample were collected for Haematological and biochemical studies. Organs were collected to record the organ weight and tissues for histology. The results showed elevation of liver enzymes due to the administration of PD at the dose level of $1000 \mathrm{mg} / \mathrm{kg}$ body weight only, while-as in case of CM, there were significant elevation of liver enzymes at all the three doses. This elevation of enzymes also correlates with histopathological changes in liver tissues. This study concludes that the method of detoxification adopted for preparing Kushta substantially reduces the elements of toxicity.
\end{abstract}

\section{INTRODUCTION}

Kushta is the finest powder form of the medicinal preparations obtained by the calcinations of metal, mineral and animal drugs. These drugs, by special process are calcinated in closed crucibles and in pits of different sizes, having varying number of cow dung cakes and with different intensity of heat. Kushta (Calcinated product) is easily absorbed in the human body and is highly efficacious in action (CCRUM, 2008). PD is unique Herbo-mineral very effective formulation of Unani System of medicine used for the treatment of renal and bladder calculi through micturation duly broken into small pieces (Abdul Hafeez, 2005; Qarabadeen, 2005; Kabeer-u-din). The dosage is $125 \mathrm{mg}$ for human subjects (CCRUM, 2008). The Hajrul-Yahood (Lime silicate or calcium silicate or Jews stone) is a fossilized stone primarily containing silicate of lime.

* Corresponding Author

Email: showkatppr@gmail.com
The stone is grinded in mortar and pestle to make the fine powder which is used. The Aab-e- mooli (Raphanus sativus Linn) is prepared by slicing the fresh radish and squeezing in a muslin cloth, the juice is collected after filtration. The juice of radish has known anti-urolithiatic and diuretic activity (Shobha et al., 2013) and the Jawakhar (Potassium carbonate) forms a strong alkaline solution.

\section{Special method of preparation of PD}

$100 \mathrm{gm}$ Hajrul-Yahood is ground into fine powder, placed in an earthenware flask and $200 \mathrm{ml}$ of the Raphanus sativus juice (Aab-e-Mooli) is added. After effective desiccation by means of Gil-e-Hikmat, the material is calcinated in a pit containing cow dung cakes. After the calcination the material is allowed to cool, $100 \mathrm{ml}$ of Aab-e-Mooli together with fine powder of Jawakhar $25 \mathrm{gm}$ (potassium carbonate) is added. The prepared material is again calcinated at a very high temperature $\left(\geq 500^{\circ} \mathrm{C}\right)$ for the required period of time. When the fire burns itself out, the PD (Kushta) is taken out. It should be light soil coloured. 
It is sieved and soaked in a bottle (CCRUM, 2008). Since there is no data available about the toxicity study of PD and also about the difference between the PD and CM to determine the effectiveness of detoxification method adopted while preparation of Kushta's. In this study an effort has been made to scientifically validate these methods and also try to determine the adverse effects of the $\mathrm{CM}$.

\section{MATERIAL AND METHODOLOGY}

\section{Test item (PD and CM)}

The PD and CM were procured from the registered Crude Unani drug dealer M/s. Ellahi Dawakhana, Unani Ayurvedic Medicines, Habak, Naseem Bagh. The drug of Kushta Hajrul-Yahood manufacturer is Hamdard Laboratory India ( $P$ Certified) Mg. Lic No U-212/78. All the Crude material was identified by Dr. M.A.Wajid (Unani Pharmacologist), Ex. Deputy Director, RRIUM, Srinagar. The PD and CM powder was mixed with RO (Reverse osmosis) water to make the suspension for oral administration.

\section{Experimental animals and maintenance}

The experimental animals (young, healthy Albino rats of Wistar Strain) were procured from IIIM, Jammu. These rats were kept in the animal house and were observed during the quarantine and acclimatization period as per the procedure described Capdevila (Capdevila et al., 2007). A veterinary examination was conducted on the rats prior to and at the end of the acclimatization and quarantine period of 14 days. The five rats of same sex were housed per cage under standard environmental condition in polypropylene cages at a temperature of $20-25^{\circ} \mathrm{C}$ with $12: 12$ hour dark and light cycle and had a free access to feed and water $a d$ libitum. The rats were provided pelleted feed procured from Pranov Agro Industries, New Delhi and RO water. The use of experimental animals in the study was approved by the Institutional Animal Ethics Committee (IAEC) of RRIUM, Srinagar which is registered with CPCSEA, India resting with registration No. 927/GO/C/06/CPCSEA.

\section{Experimental design}

The sub-chronic oral toxicity was performed according to OECD-408 guideline (OECD 408., 1998). The rats were randomly divided into 14 groups as shown in table 1 ( 7 male and 7 female groups) each group consisted of 5 rats.

All the animals were closely observed up to 4 hours post dosing to examine any adverse toxic signs, behavioural changes etc. The body weight of the rats was recorded weekly. Feed and water consumption / rat / 24 hours were recorded before dosing and then weekly upto 13 weeks. On the $91^{\text {st }}$ day, after over-night fast, all the animals were sacrificed by withdrawing blood in a syringe from the dorsal vena cava after opening the abdomen under ISOFLURANE anaesthesia. All the animals were dissected to check macroscopic morphology of the body organs. The organs such as liver, lung, kidney, adrenal gland, pancreas, spleen, brain, ovary/testes and heart were collected to determine the relative organ weight followed by grossing for the collection of tissues to evaluate Histopathological studies.

Table 1: Description of rat groups.

\begin{tabular}{llll}
\hline Group No. & Male/Female & Description & $\begin{array}{c}\text { Dose for 28 days (Daily } \\
\text { in the morning) }\end{array}$ \\
\hline Group I & & Control & RO water (Vehicle only) \\
Group II & & PD Treated & $1000 \mathrm{mg} / \mathrm{kg}$ body wt. \\
Group III & PD Treated & $500 \mathrm{mg} / \mathrm{kg}$ body wt. \\
Group IV & Male & PD Treated & $250 \mathrm{mg} / \mathrm{kg}$ body wt. \\
Group V & & CM Treated & $1000 \mathrm{mg} / \mathrm{kg}$ body wt. \\
Group VI & & CM Treated & $500 \mathrm{mg} / \mathrm{kg}$ body wt. \\
Group VII & CM Treated & $250 \mathrm{mg} / \mathrm{kg}$ body wt. \\
\hline Group VIII & & Control & RO water (Vehicle only) \\
Group IX & & PD Treated & $1000 \mathrm{mg} / \mathrm{kg}$ body wt. \\
Group X & \multirow{2}{*}{ Group XI } & PD Treated & $500 \mathrm{mg} / \mathrm{kg}$ body wt. \\
Group XII & & PD Treated & $250 \mathrm{mg} / \mathrm{kg}$ body wt. \\
Group XIII & & CM Treated & $1000 \mathrm{mg} / \mathrm{kg}$ body wt. \\
Group XIV & CM Treated & $500 \mathrm{mg} / \mathrm{kg}$ body wt. \\
\hline
\end{tabular}

Dosage of PD in Humans: 1 tablet of $125 \mathrm{mg}$ a day orally with water. This amounts to about $2 \mathrm{mg} / \mathrm{kg} /$ day in human subjects. Table 2 shows the corresponding dose level in rats.

Curry and his team mates has previously calculated interspecies dose conversion from rats weighing $100 \mathrm{gm}$ body weight to humans with $60 \mathrm{~kg}$ body weight. The equivalent surface area dosage conversion factor from rat to humans was 1/7 (Curry et al., 2011).

Table 2: Corresponding dose level in rats.

\begin{tabular}{ll}
\hline Particulars of Study & $\begin{array}{l}\text { Sub-chronic toxicity study } \\
1000,500 \text { and } 250 \mathrm{mg} / \mathrm{kg} \text { body weight } \\
\text { (Corresponding to } 70 \mathrm{X}, 35 \mathrm{X} \text { and } 17.5 \mathrm{X} \text { the } \\
\text { Dose level }\end{array}$ \\
$\begin{array}{l}\text { Repeated daily dosing by oral route } \\
\text { Rosing Schedule }\end{array}$ & $\begin{array}{l}\text { Re Days } \\
\text { Period of Observation }\end{array}$ \\
Observation Parameters & See Text
\end{tabular}

\section{Biochemistry parameters}

Biochemical parameters were studied in serum obtained after centrifugation of blood at 2000 RPM for 15 minutes on the day of the rat sacrifice. Biochemical parameters were determined on fully automatic biochemistry analyzer (XL-600 TRANSASIA) using ERBA kits.

Liver function tests- aspartate aminotransferase (AST), alanine aminotransferase (ALT), alkaline phosphotase (ALP), Total bilirubin, total protein, and albumin, and kidney function tests- blood urea, serum uric acid and serum creatinine were done. In addition to this other Metabolic function tests such as blood glucose, serum Cholesterol and serum Triglyceride were estimated.

\section{Haematological parameters}

Haematological parameters were analyzed in freshly collected blood in blue top vacutainer containing EDTA anticoagulant. The blood was gently mixed with the EDTA anticoagulant coated on the tube walls. Haematological parameters were determined on fully automatic haematological analyzer 
(Sysmex XT-2000iV Sysmex Corporation Japan) having animal version software. Haematological parameters such as Haemoglobin Conc. WBC count, RBC count, haematocrit, Mean Corpuscular Volume, Mean Corpuscular Haemoglobin Concentration, Mean Corpuscular Haemoglobin, Platelet Count, differential leukocyte count - Neutrophil \%, Lymphocyte \%, Monocyte \%, Eosinophil \% and basophil \%, and Reticulocyte count were studied.

\section{Histopathology}

Tissue samples were collected from the organs of control rats as well as treated male/female rats of the sub-chronic study. The tissue collected from the organs such as liver, lung, kidney, adrenal gland, pancreas, spleen, brain, ovary/testes and heart ware numbered for identification and then transferred to tissue cassettes (SS) to enable fixation in $10 \%$ formalin for 3 to 5 days followed by the tissue processing which was carried on Automatic tissue processor Model No. 1020 (LIECA make Germany). The tissue processing included dehydration in graded isopropyl alcohol, clearing in xylene I \& II, impregnation in paraffin wax and finally tissue blocks was prepared on paraffin block making Model No. $1150 \mathrm{H}+\mathrm{C}$ (LIECA make Germany). Section cutting of tissue blocks was done using microtome (YARCO) to the thickness of 3 - 5 microns. The tissue sections were fixed on the slide by heat technique followed by the staining by Haematoxylin and Eosin stains. The staining was carried by Automatic slide stainer (THERMO MAKE Germany). After staining the tissue section were mounted with DPX to prevent any damage to the stained tissue which was carried on Auto cover slipper Model No. CV5030 (LIECA make Germany). The stained tissue sections were examined under microscope 10x and 40x objective to check the adverse effects of drug on cell morphology as well as on the cell organelles.

\section{Statistical analysis}

All results are expressed as mean \pm standard deviation. Comparison of all results on body weight, feed \& water consumption, haematological value, biochemical values, were performed using one way analysis of variance (ANOVA) method using statistical software Graph Pad Prism version 6.07. Probability of 0.05 or small $(p \leq 0.05)$ was used as the criterion of significance.

\section{RESULTS}

\section{Average mean body weight}

The rats treated with PD and CM at the dose of 1000 , 500 and $250 \mathrm{mg} / \mathrm{kg}$ of body weight were found to grow and gain body weight normally and there were no any adverse effect found in the body weight gains. Figure 1a, 1b,1c and 1d shows the body weight gain of rats in sub chronic oral toxicity study.

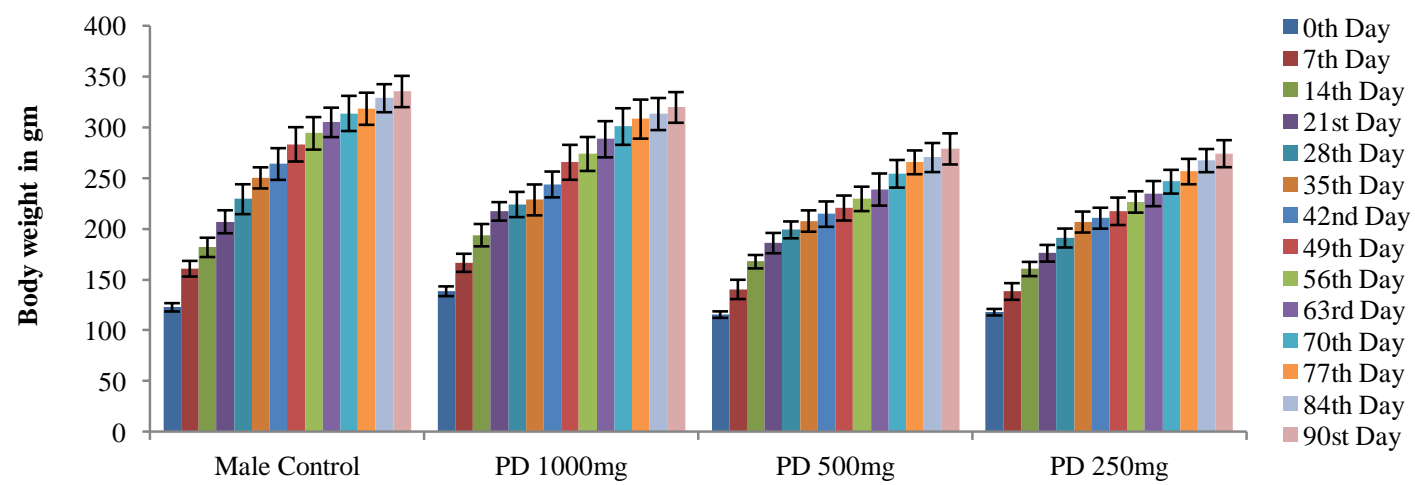

Fig. 1a : Average body weight gain of male rats in sub chronic oral toxicity study of PD.

The values are expressed as mean $\pm \mathrm{SD}$. $\mathrm{n}=5$ in each group. ${ }^{\mathrm{a}} p<0.05$ as compared with the controls at the same time (one-way ANOVA).

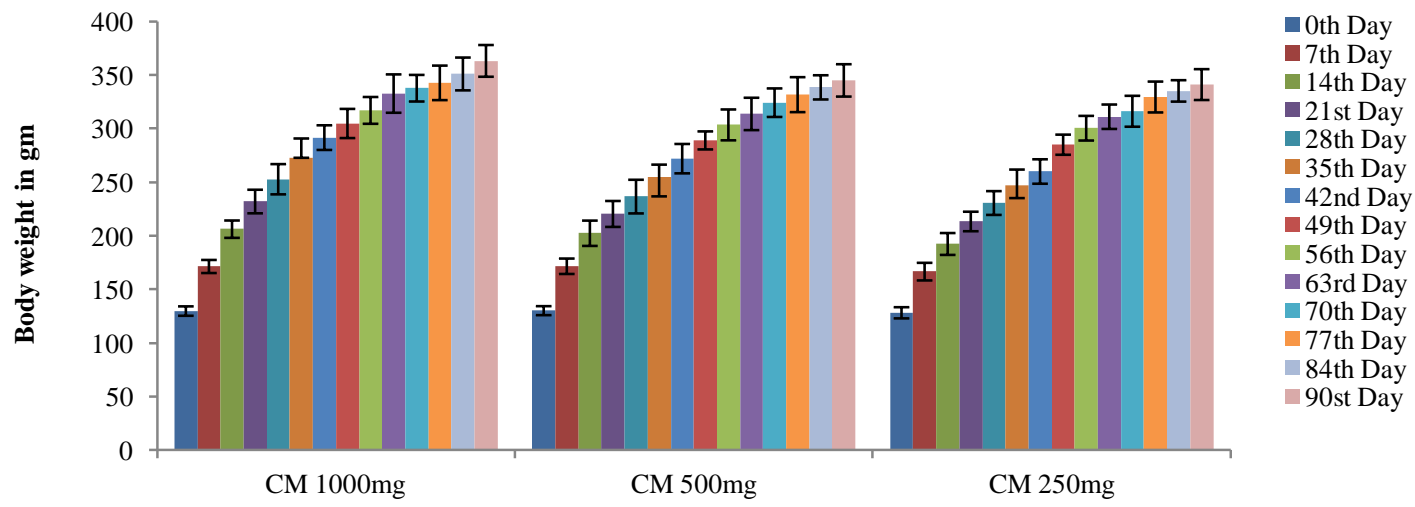

Fig. 1b :Average body weight gain of male rats in sub chronic oral toxicity study of CM.

The values are expressed as mean \pm SD. $n=5$ in each group. ${ }^{a} p<0.05$ as compared with the controls at the same time (one-way ANOVA). 


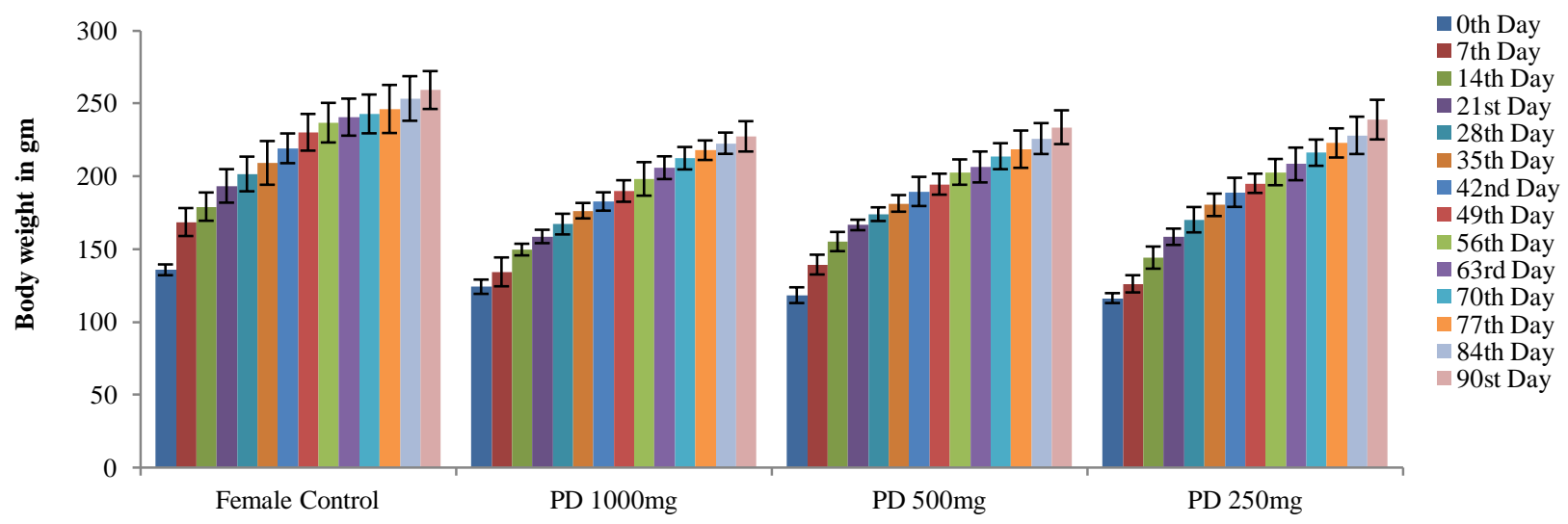

Fig. 1c: Average body weight gain of female rats in sub chronic oral toxicity study of PD.

The values are expressed as mean \pm SD. $n=5$ in each group. ${ }^{a} p<0.05$ as compared with the controls at the same time (one-way ANOVA).

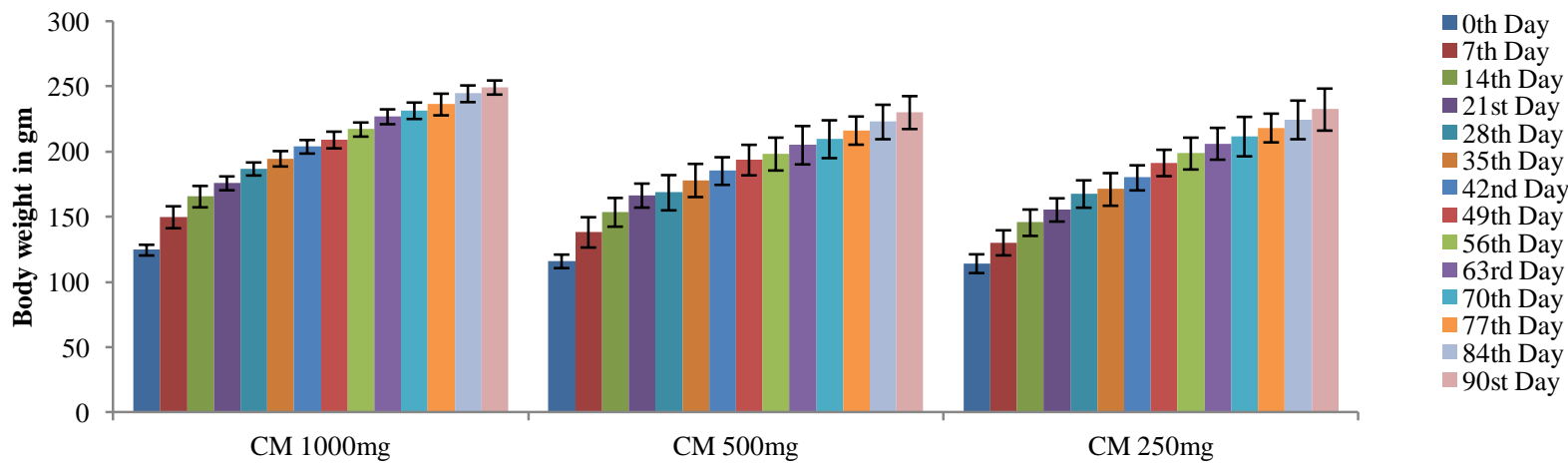

Fig. 1d: Average body weight gain of female rats in sub chronic oral toxicity study of CM.

The values are expressed as mean $\pm \mathrm{SD}$. $\mathrm{n}=5$ in each group. ${ }^{\mathrm{a}} p<0.05$ as compared with the controls at the same time (one-way ANOVA)

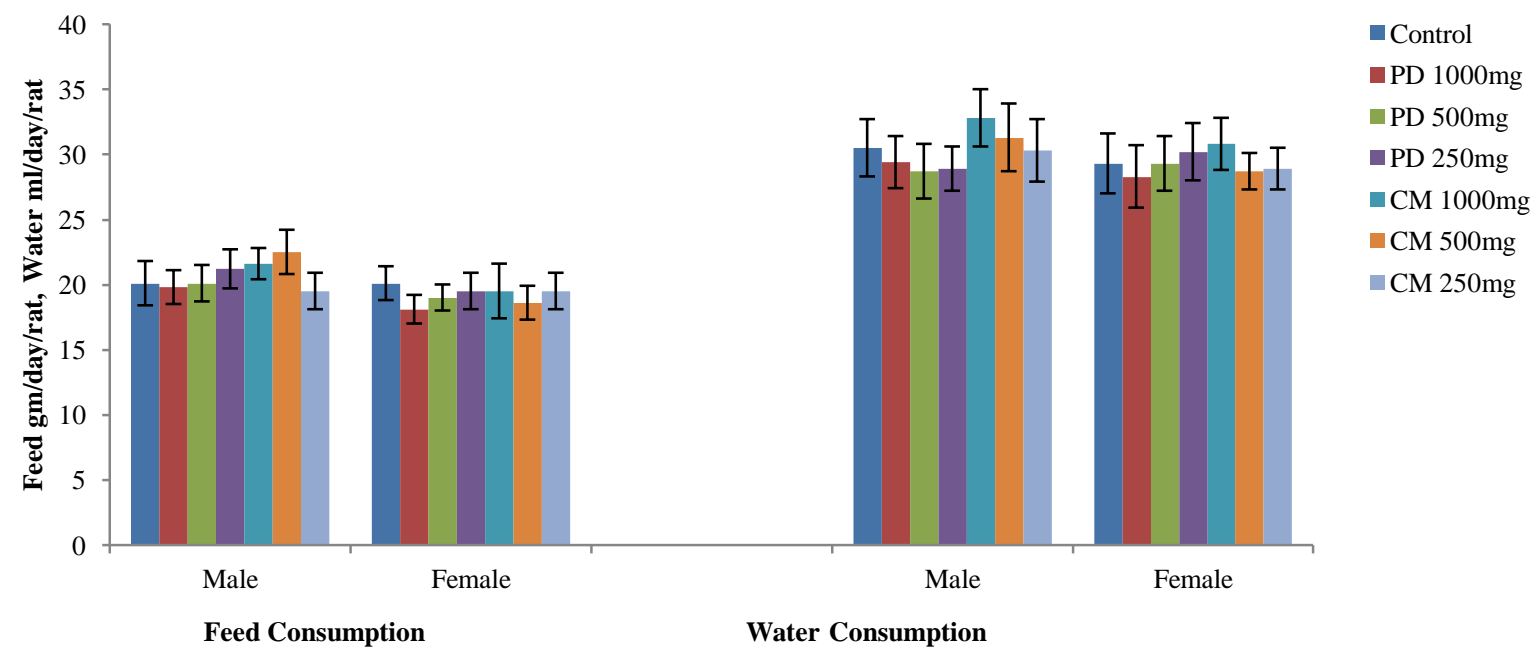

Fig. 2: Average Feed and water consumption of male and female rats in sub chronic oral toxicity study of PD and CM. The values are expressed as mean \pm SD. $n=5$ in each group. ${ }^{a} p<0.05$ as compared with the controls at the same time (one-way ANOVA) 
Table 3a: Relative organ weight of male rats in sub-chronic oral toxicity study of PD and CM.

\begin{tabular}{|c|c|c|c|c|c|c|c|}
\hline \multirow[b]{2}{*}{ Organ } & \multicolumn{7}{|c|}{ Male } \\
\hline & Control & $\begin{array}{c}\text { PD } \\
1000 \mathrm{mg}\end{array}$ & $\begin{array}{c}\text { PD } \\
500 \mathrm{mo}\end{array}$ & $\begin{array}{c}\text { PD } \\
250 \mathrm{mg}\end{array}$ & $\begin{array}{c}\mathrm{CM} \\
1000 \mathrm{mg}\end{array}$ & $\begin{array}{c}\mathrm{CM} \\
500 \mathrm{mg}\end{array}$ & $\begin{array}{c}\text { CM } \\
250 \mathrm{mo}\end{array}$ \\
\hline $\begin{array}{l}\text { Spleen (gm) } \\
\text { (g) }\end{array}$ & $0.295 \pm 0.12$ & $0.309 \pm 0.11$ & $0.292 \pm 0.10$ & $0.312 \pm 0.09$ & $0.297 \pm 0.1$ & $0.301 \pm 0.09$ & $0.307 \pm 0.09$ \\
\hline Right adrenal (gm) & $0.012 \pm 0.007$ & $0.010 \pm 0.006$ & $0.011 \pm 0.007$ & $0.011 \pm 0.009$ & $0.012 \pm 0.009$ & $0.013 \pm 0.008$ & $0.012 \pm 0.009$ \\
\hline Left adrenal (gm) & $0.011 \pm 0.005$ & $0.013 \pm 0.006$ & $0.012 \pm 0.007$ & $0.012 \pm 0.006$ & $0.014 \pm 0.009$ & $0.012 \pm 0.008$ & $0.011 \pm 0.007$ \\
\hline Heart (gm) & $0.292 \pm 0.10$ & $0.293 \pm 0.13$ & $0.324 \pm 0.12$ & $0.288 \pm 0.12$ & $0.284 \pm 0.11$ & $0.279 \pm 0.12$ & $0.299 \pm 0.10$ \\
\hline Lung (gm) & $0.639 \pm 0.18$ & $0.580 \pm 0.15$ & $0.616 \pm 0.14$ & $0.588 \pm 0.16$ & $0.591 \pm 0.12$ & $0.561 \pm 0.19$ & $0.600 \pm 0.11$ \\
\hline Right kidney (gm) & $0.323 \pm 0.12$ & $0.293 \pm 0.10$ & $0.328 \pm 0.14$ & $0.320 \pm 0.12$ & $0.289 \pm 0.10$ & $0.291 \pm 0.16$ & $0.308 \pm 0.12$ \\
\hline Left kidney (gm) & $0.308 \pm 0.11$ & $0.280 \pm 0.10$ & $0.312 \pm 0.13$ & $0.309 \pm 0.12$ & $0.276 \pm 0.09$ & $0.262 \pm 0.14$ & $0.302 \pm 0.13$ \\
\hline Right testis (gm) & $0.426 \pm 0.15$ & $0.455 \pm 0.16$ & $0.412 \pm 0.13$ & $0.492 \pm 0.15$ & $0.362 \pm 0.11$ & $0.403 \pm 0.10$ & $0.442 \pm 0.13$ \\
\hline Left testis (gm) & $0.411 \pm 0.15$ & $0.436 \pm 0.16$ & $0.407 \pm 0.12$ & $0.407 \pm 0.10$ & $0.341 \pm 0.14$ & $0.390 \pm 0.13$ & $0.400 \pm 0.11$ \\
\hline Liver (gm) & $2.804 \pm 0.50$ & $2.693 \pm 0.55$ & $2.933 \pm 0.44$ & $2.881 \pm 0.57$ & $2.480 \pm 0.59$ & $2.618 \pm 0.6$ & $2.833 \pm 0.50$ \\
\hline Pancreas (gm) & $0.198 \pm 0.08$ & $0.171 \pm 0.07$ & $0.177 \pm 0.09$ & $0.186 \pm 0.05$ & $0.175 \pm 0.08$ & $0.186 \pm 0.09$ & $0.180 \pm 0.1$ \\
\hline
\end{tabular}

The values are expressed as mean $\pm \mathrm{SD}$. $\mathrm{n}=5$ in each group. ${ }^{\mathrm{a}} p<0.05$ as compared with the controls at the same time (one-way ANOVA).

Table 3b: Relative organ weight of female rats in sub-chronic oral toxicity study of PD and CM.

\begin{tabular}{|c|c|c|c|c|c|c|c|}
\hline \multirow[b]{2}{*}{ Organ } & \multicolumn{7}{|c|}{ Female } \\
\hline & Control & $\begin{array}{c}\text { PD } \\
1000 \mathrm{mg}\end{array}$ & $\begin{array}{c}\text { PD } \\
500 \mathrm{mg}\end{array}$ & $\begin{array}{c}\text { PD } \\
250 \mathrm{mg}\end{array}$ & $\begin{array}{c}\mathrm{CM} \\
1000 \mathrm{mg}\end{array}$ & $\begin{array}{c}\mathrm{CM} \\
500 \mathrm{mg}\end{array}$ & $\begin{array}{c}\mathrm{CM} \\
250 \mathrm{mg}\end{array}$ \\
\hline Spleen (gm) & $0.293 \pm 0.12$ & $0.297 \pm 0.13$ & $0.311 \pm 0.14$ & $0.277 \pm 0.10$ & $0.315 \pm 0.16$ & $0.367 \pm 0.12$ & $0.292 \pm 0.12$ \\
\hline Right adrenal (gm) & $0.012 \pm 0.005$ & $0.014 \pm 0.006$ & $0.011 \pm 0.008$ & $0.012 \pm 0.007$ & $0.0013 \pm 0.009$ & $0.010 \pm 0.008$ & $0.011 \pm 0.006$ \\
\hline Left adrenal (gm) & $0.011 \pm 0.005$ & $0.014 \pm 0.006$ & $0.010 \pm 0.007$ & $0.011 \pm 0.009$ & $0.012 \pm 0.009$ & $0.009 \pm 0.008$ & $0.013 \pm 0.008$ \\
\hline Heart (gm) & $0.288 \pm 0.10$ & $0.296 \pm 0.11$ & $0.280 \pm 0.12$ & $0.295 \pm 0.09$ & $0.301 \pm 0.10$ & $0.284 \pm 0.09$ & $0.288 \pm 0.11$ \\
\hline Lung (gm) & $0.620 \pm 0.13$ & $0.673 \pm 0.10$ & $0.563 \pm 0.15$ & $0.525 \pm 0.11$ & $0.562 \pm 0.13$ & $0.525 \pm 0.14$ & $0.565 \pm 0.16$ \\
\hline Right kidney (gm) & $0.298 \pm 0.08$ & $0.311 \pm 0.11$ & $0.299 \pm 0.08$ & $0.307 \pm 0.07$ & $0.277 \pm 0.06$ & $0.295 \pm 0.07$ & $0.299 \pm 0.07$ \\
\hline Left kidney (gm) & $0.274 \pm 0.07$ & $0.291 \pm 0.10$ & $0.282 \pm 0.07$ & $0.288 \pm 0.06$ & $0.269 \pm 0.05$ & $0.286 \pm 0.08$ & $0.292 \pm 0.09$ \\
\hline Right Ovary (gm) & $0.025 \pm 0.009$ & $0.022 \pm 0.008$ & $0.027 \pm 0.006$ & $0.021 \pm 0.007$ & $0.022 \pm 0.008$ & $0.026 \pm 0.009$ & $0.022 \pm 0.008$ \\
\hline Left Ovary (gm) & $0.023 \pm 0.008$ & $0.020 \pm 0.006$ & $0.023 \pm 0.007$ & $0.019 \pm 0.008$ & $0.019 \pm 0.007$ & $0.022 \pm 0.009$ & $0.019 \pm 0.008$ \\
\hline Liver (gm) & $3.01 \pm 0.55$ & $2.74 \pm 0.42$ & $3.11 \pm 0.57$ & $3.00 \pm 0.43$ & $2.700 \pm 0.58$ & $3.084 \pm 0.59$ & $2.77 \pm 0.55$ \\
\hline Pancreas (gm) & $0.173 \pm 0.06$ & $0.199 \pm 0.109$ & $0.171 \pm 0.07$ & $0.186 \pm 0.09$ & $0.189 \pm 0.08$ & $0.180 \pm 0.10$ & $0.186 \pm 0.07$ \\
\hline
\end{tabular}

The values are expressed as mean $\pm \mathrm{SD} . \mathrm{n}=5$ in each group. ${ }^{\mathrm{a}} p<0.05$ as compared with the controls at the same time (one-way ANOVA).

\section{Mean feed and water consumption}

The average feed and water consumption of PD and CM treated groups were found to be unaffected as there were no statistically significant changes in the average feed and water consumption of treated rat groups when compared with the respective controls as shown in figure 2 .

Relative organ weight of male and female rats in sub-chronic oral toxicity study (Organ weight in gm/100gram of body weight)

The relative organ weight of male and female rats in subchronic oral toxicity study were found unaltered by the PD and $\mathrm{CM}$ treated rats when comparing with the respective controls as shown in table $3 \mathrm{a}$ and $3 \mathrm{~b}$.

\section{Biochemistry parameters}

The results of Biochemical parameters of PD and CM treated rat groups did not show any statistically significant change when compared with the control rat groups except in PD treated rats at the dose level of $1000 \mathrm{mg} / \mathrm{kg}$ body wt. and at all the three dose levels of CM treated rats there is elevation of liver enzymes ALT, AST and ALP as shown in Figure-3a, $3 \mathrm{~b}$ and $3 \mathrm{c}$.

\section{Haematology parameters}

The results of Haematological parameters of the PD and CM treated male and female rats did not show statistically significant change when compared with the respective controls. Figure $4 \mathrm{a}, 4 \mathrm{~b} \& 4 \mathrm{c}$ shows the haematological parameters of male and female rats.

\section{Histopathology}

The histopathological examination of vital organs such as spleen, pancreas, adrenal gland, testes/ovaries, heart and lung did not reveal any abnormality after administration of PD and CM. However liver and kidney of PD (1000mg/kg only) and CM treated rats at all the three doses showed some level of toxicity concerns as shown in figure 5 and 6. 


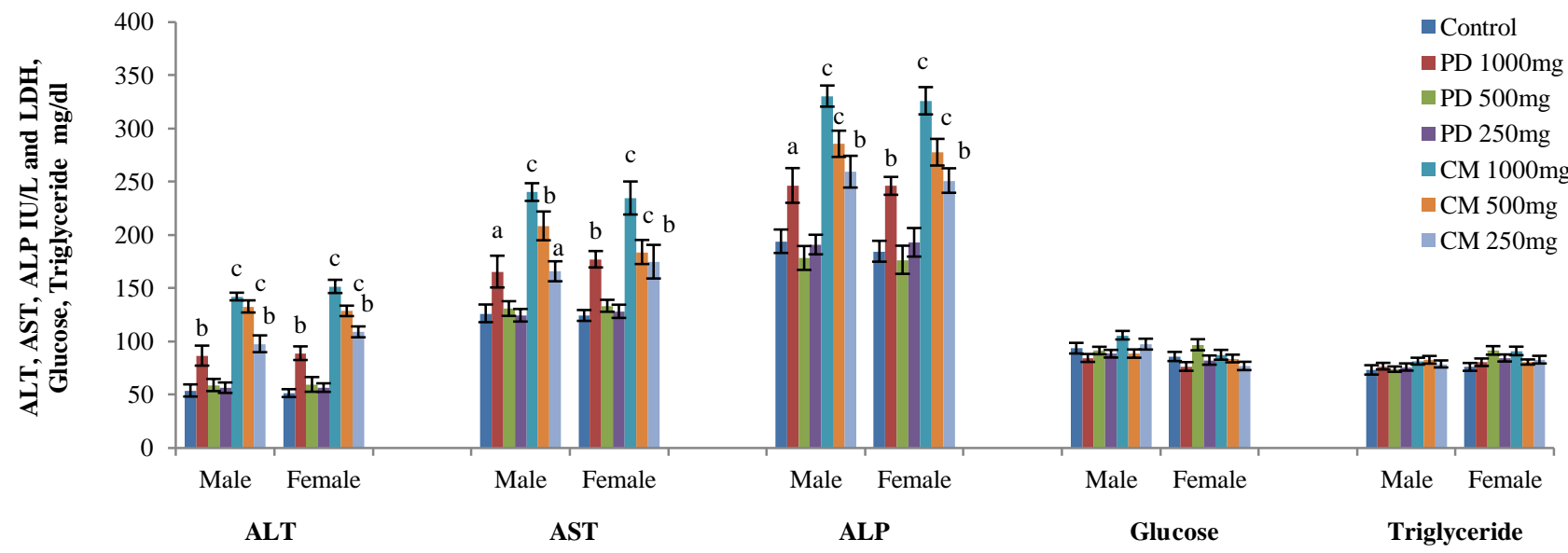

Fig. 3a: Biochemistry parameters ALT, AST, ALP, Glucose and Triglyceride of male and female rats in sub chronic oral toxicity study of PD and CM. The values are expressed as mean \pm SD. $\mathrm{n}=5$ in each group. ${ }^{\mathrm{a}} p<0.05=$ significant, ${ }^{\mathrm{b}} p<0.01=$ highly significant, ${ }^{\mathrm{c}} p<0.001=$ very highly significant as compared with the controls at the same time (one-way ANOVA).

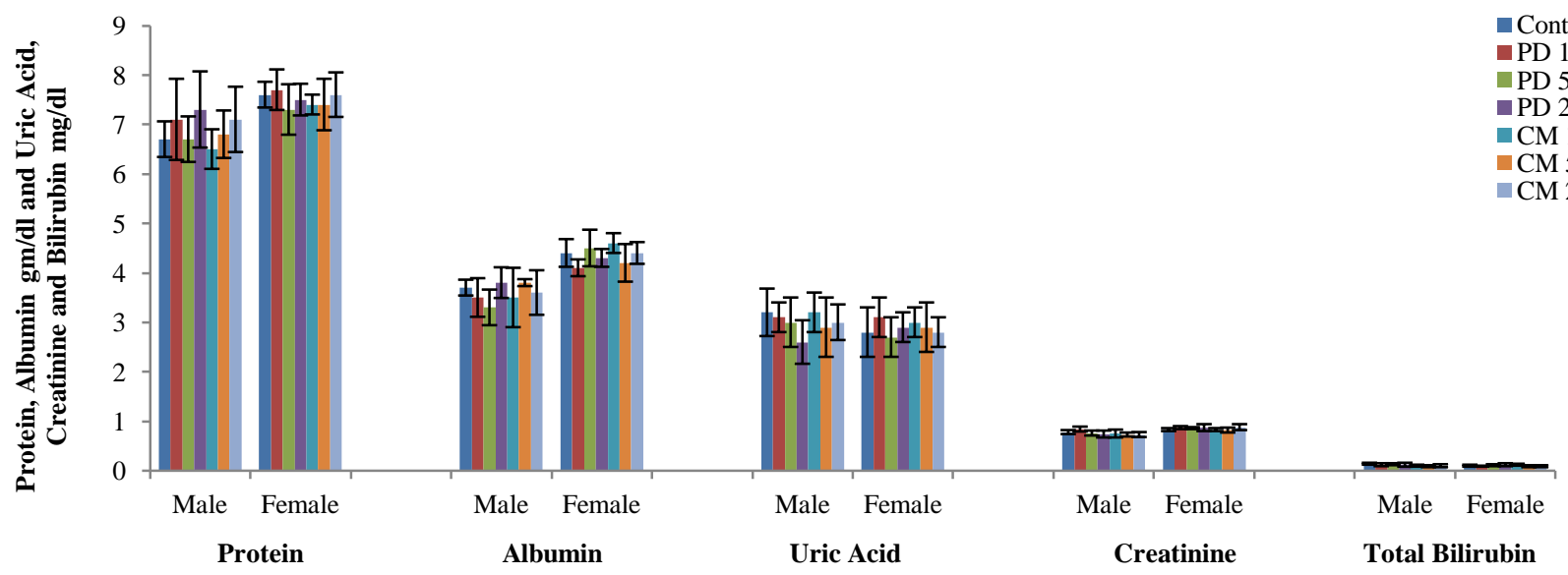

Fig. 3b: Biochemistry parameters Total Protein, Albumin, Uric Acid, Creatinine and Total Bilirubin of male and female rats in sub chronic oral toxicity study of PD and CM. The values are expressed as mean \pm SD. $\mathrm{n}=5$ in each group. ${ }^{\mathrm{a}} p<0.05$ as compared with the controls at the same time (one-way ANOVA).

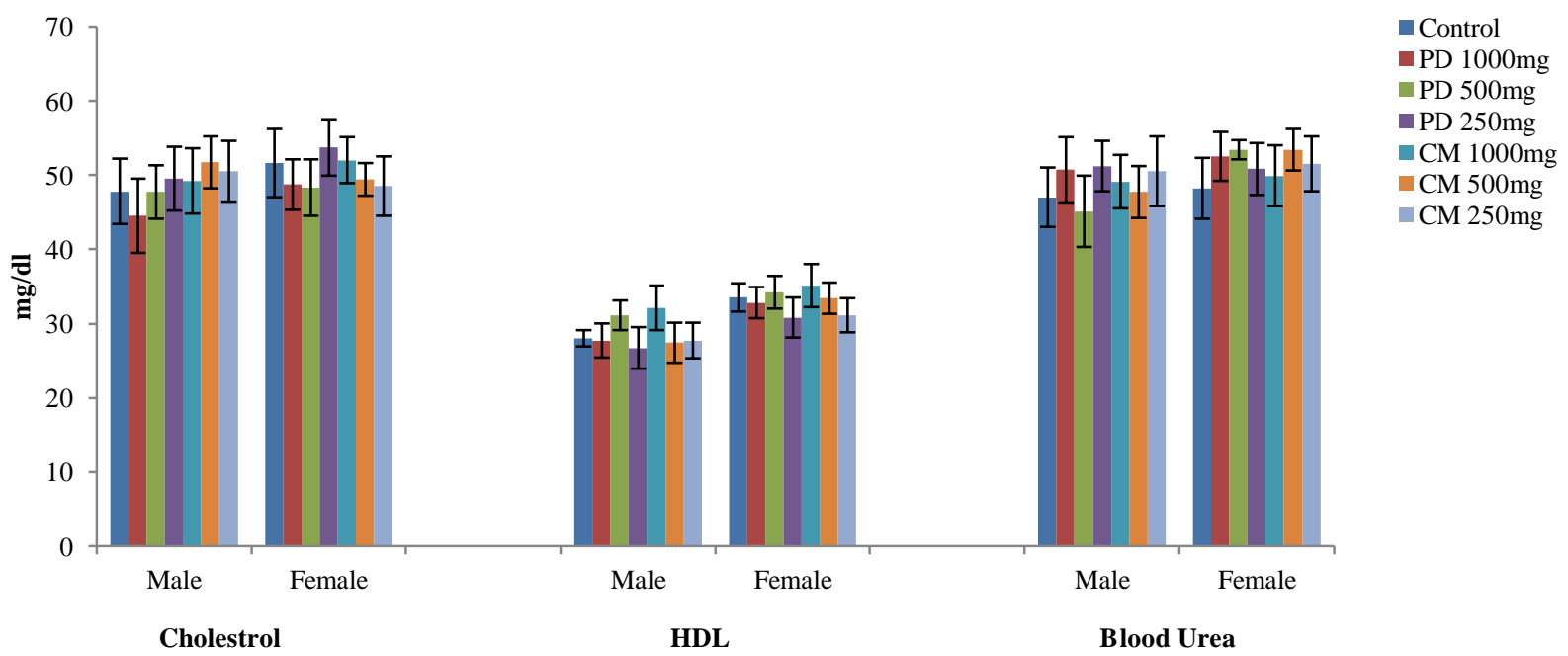

Fig. 3c: Biochemistry parameters Serum Cholestrol, HDL and Blood Urea of male and female rats in sub chronic oral toxicity study of PD and CM. The values are expressed as mean \pm SD. $n=5$ in each group. ${ }^{a} p<0.05$ as compared with the controls at the same time (one-way ANOVA) 


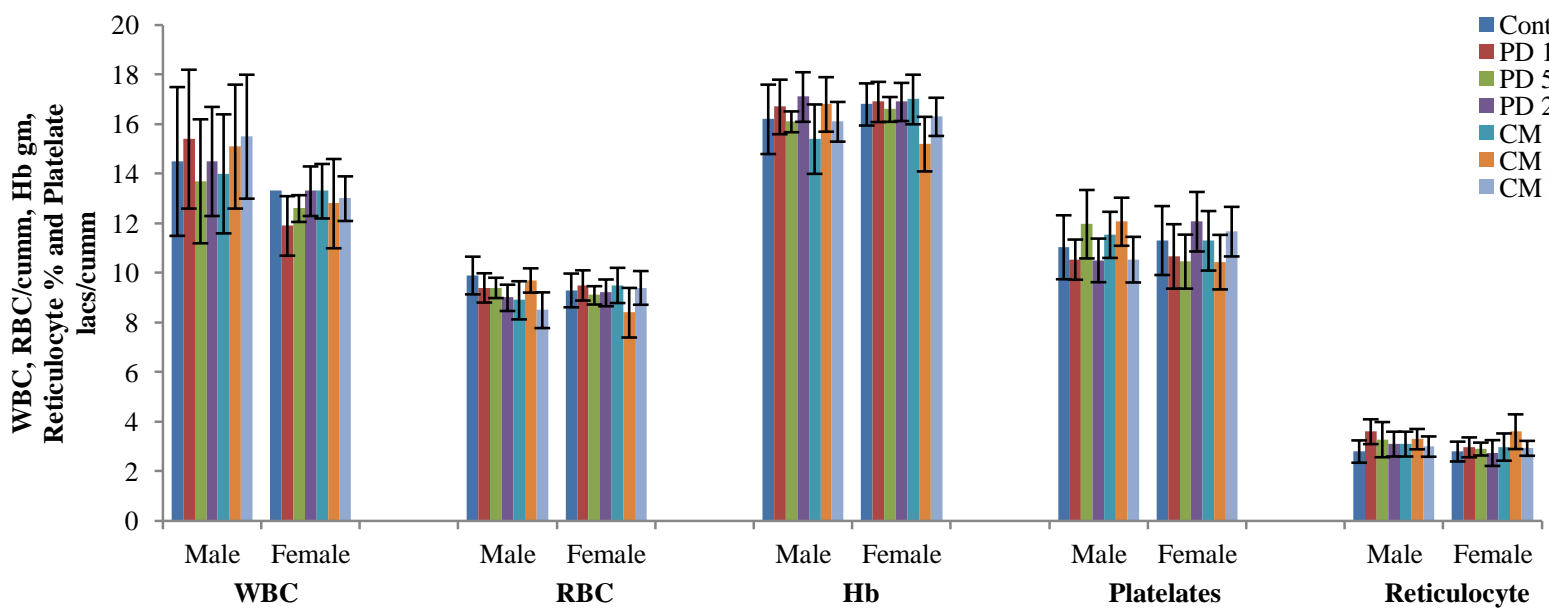

Fig 4a: Haematological parameters WBC Count, RBC Count, Haemoglobin, Platelate and Reticulocyte count of male and female rats in sub chronic oral toxicity study of PD and CM. The values are expressed as mean \pm SD. $n=5$ in each group. ${ }^{a} p<0.05$ as compared with the controls at the same time (one-way ANOVA)

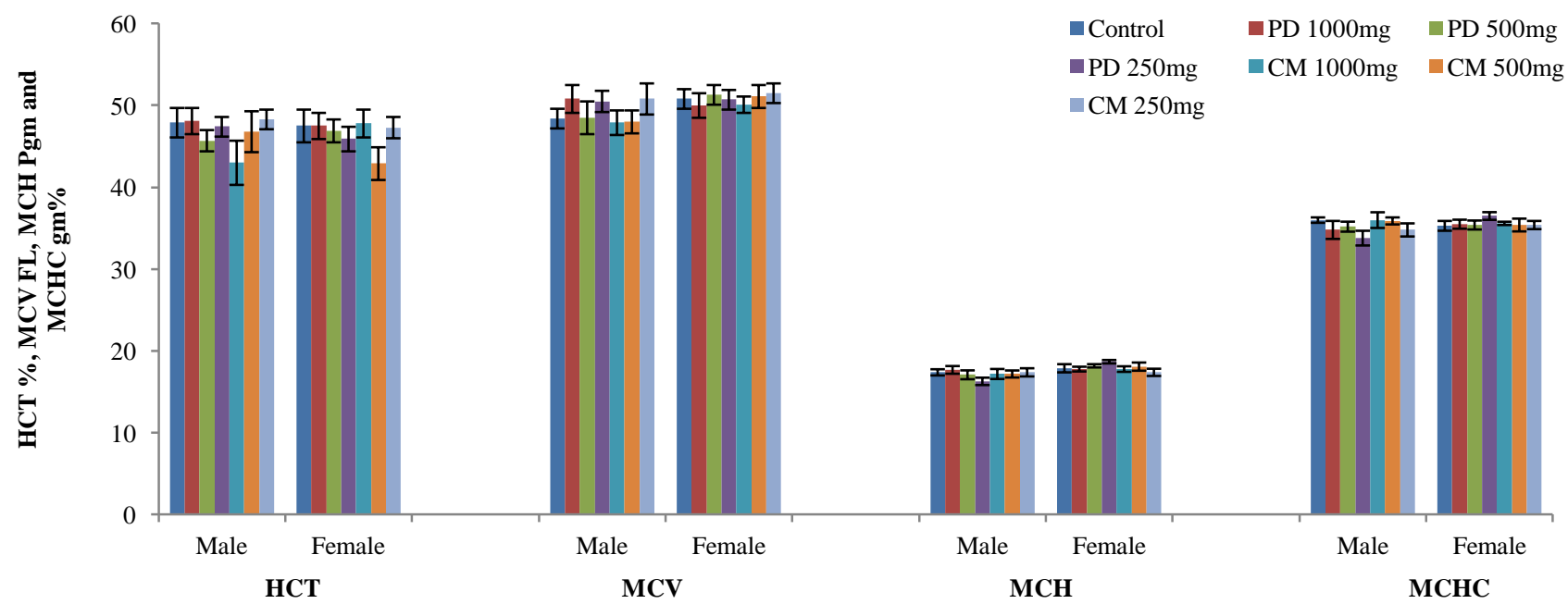

Fig. 4b : Haematological parameters HCT, MCV, MCH and MCHC of male and female rats in sub chronic oral toxicity study of PD and CM. The values are expressed as mean \pm SD. $n=5$ in each group. ${ }^{a} p<0.05$ as compared with the controls at the same time (one-way ANOVA).

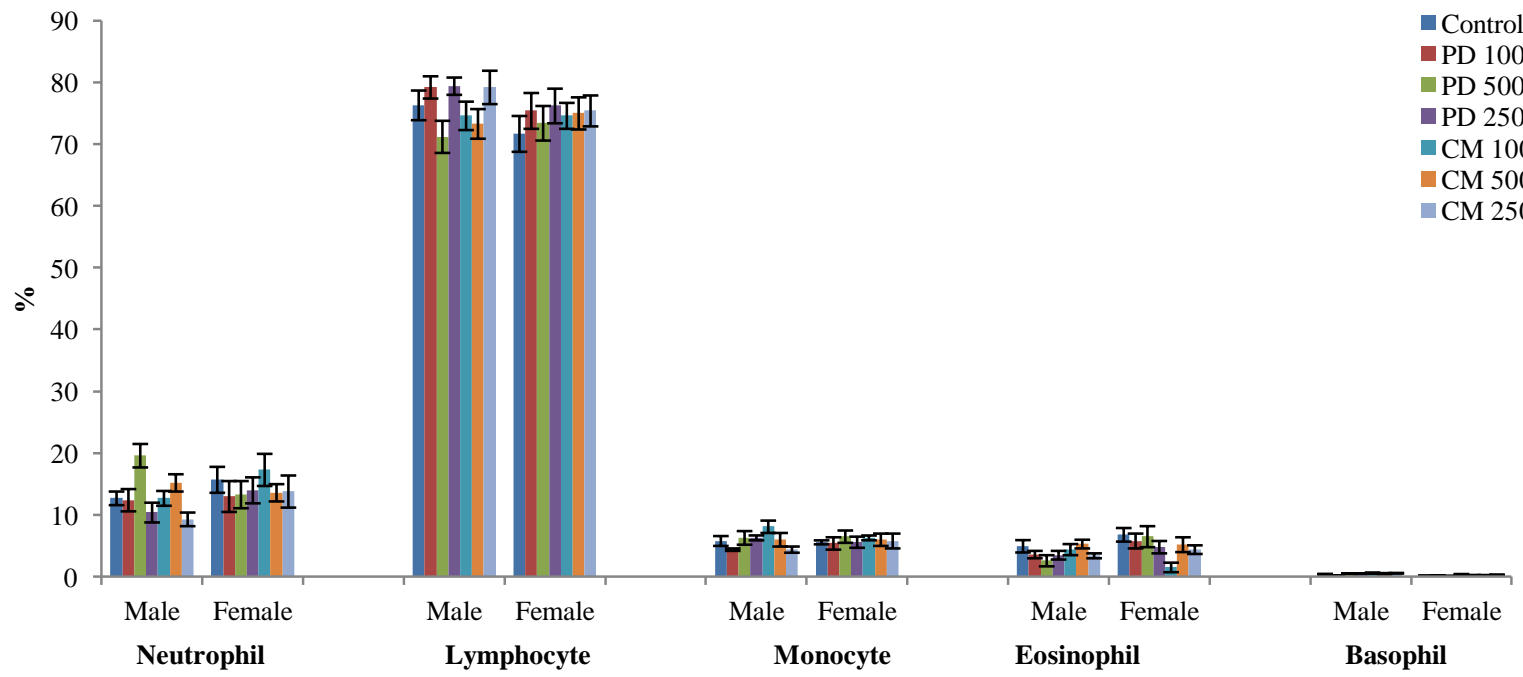

Fig. 4c: Haematological parameter DLC - Neutrophil, Lymphocyte, Monocyte, Eosinophil and Basophil percentage of male and female rats in sub chronic oral toxicity study of PD and CM. The values are expressed as mean \pm SD. $n=5$ in each group. ${ }^{a} p<0.05$ as compared with controls at the same time (one-way ANOVA) 

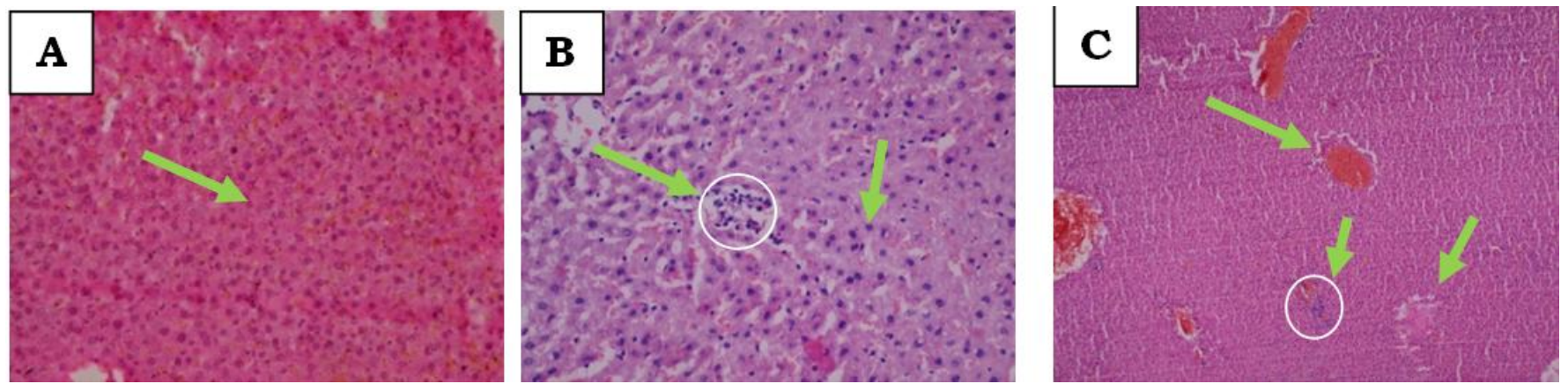

Fig. 5: Photomicrographs of Liver: [40X10X4] except (C) i.e. 10X10X4]. (A) Control - Showing normal hepatocytes. (B) PD 1000mg/kg body Wt. -.

Showing mild congestion; mild Kupffer's cell proliferation and hepatocellular swelling. (C) CM 1000 mg/kg body Wt. - Showing moderate vascular congestion, mild cellular degeneration and occasional Kupffer's cell proliferation.
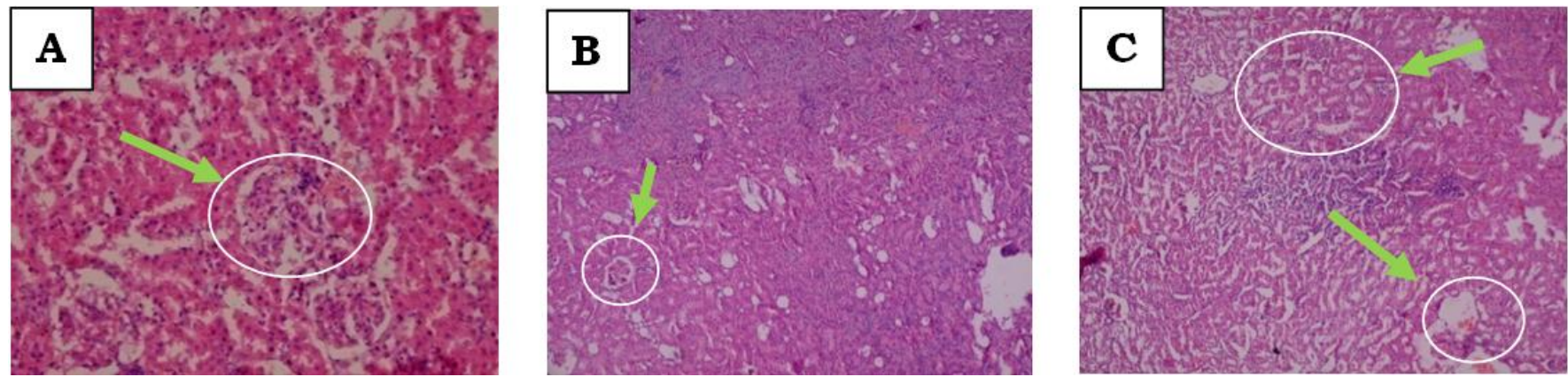

Fig. 6:Photomicrographs of Kidney: [40X10X4] except (B \& C) i.e. 10X10X4]. (A) Control - Showing normal tubules and glomeruli. (B) PD 1000mg/kg body Wt. - Showing convoluted tubules revealed cellular swelling of lining tubular epithelium with reduced lumen, loss of tubular epithelium was frequently seen but basement membrane intact. (C) CM $1000 \mathrm{mg} / \mathrm{kg}$ body Wt. - Showing apical lysis of tubular epithelium, mild glomerular congestion.

\section{DISCUSSION}

In this study a limit dose of $1000 \mathrm{mg} / \mathrm{kg}$ body weight and its two sub fractions 500 and $250 \mathrm{mg} / \mathrm{kg}$ body weight were selected for daily oral administration of PD and CM to the both male and female rats. Changes in general body weight, feed and water consumption of the animals were used as the cage side indicators of the adverse effects of drugs (Nandy et al., 2012; Hilaly et al., 2004; Sireetawong et al., 2008). Oral administration of PD and CD at three dose levels of 1000,500 and $250 \mathrm{mg} / \mathrm{kg}$ body weight did not produce significant changes in cage side observation, body weight gain, feed and water consumption. The relative organ weight of the vital organ of the rats are important parameter to determine the organomegaly which may result do to the deposition of drug in the organ. The relative organ weight of PD and CM treated rats were found statistically non significant when compared with the control rats. The biochemical parameters of PD and CM treated rats were found comparable to control parameters except there were elevation in liver enzymes GOT, GPT and ALP found in PD treated rats at the dose level of $1000 \mathrm{mg} / \mathrm{kg}$ body weight (70X, $\mathrm{X}$ is the extrapolated therapeutic dose in rats) and at all the three dose levels of CM treated rats. The higher doses of the PD were associated with some toxicity concern. There were no treatment related effects of $\mathrm{PD}$ and $\mathrm{CM}$ treated rats on the haematology parameters when compared with the control rats.
The histopathological examination of vital organs such as spleen, pancreas, adrenal gland, testes/ovaries, heart and lung did not reveal any abnormality after administration of $\mathrm{PD}$ and $\mathrm{CM}$. However liver (Figure 5) of PD (1000mg/kg only) and CM treated rats shows moderate vascular congestion, Kupffer's cell proliferation, hepatocellular swelling and cellular degeneration and also the kidney tissues (Figure 6) of PD (1000 mg/kg only) and CM shows convoluted tubules cellular swelling of lining tubular epithelium with reduced lumen, loss of tubular epithelium was frequently seen but basement membrane intact, apical lysis of tubular epithelium and mild glomerular congestion.

The result therefore suggests that the PD is potentially safe for oral consumption at the therapeutic dose level, While as the drug was found to effect liver and kidney tissues at $1000 \mathrm{mg} / \mathrm{kg}$ body weight (70X, $\mathrm{X}$ is the extrapolated therapeutic dose in rats). The Crude material was found to be unsafe for oral consumption as the Crude material was found to potentially induce hepatic and kidney tissue damage at all the three dose levels. This indicates that the method of detoxification adopted by the Unani System of Medicine while preparation of Kushta reduces the elements of toxicity or downgrade them to the level at which drug can be used safely. It is also concluded that patients having altered kidney and liver parameters may be given this drug with caution under medical supervision and laboratory monitoring. 


\section{ACKNOWLEDGEMENTS}

The authors thank the Director General, Central Council for Research in Unani Medicine, New Delhi for his interest in the study, guidance, administrative support. The authors also thank Dr. Sudhir Srivastava, Consultant, DST Project, for his technical guidance and encouragement. The authors are also grateful to Miss Aaliya Amir, Mr. Ashaq Ahmad, Bashir Ahmad and Shafiq Ahmad for the support in carrying out the experimental work and maintenance of animal house.

Financial support and sponsorship: The authors thank Department of Science and Technology, New Delhi for funding and also for Establishing a National Facility for Non Clinical Safety Evaluation of Unani Drugs.

Conflict of Interests: There are no conflicts of interest.

\section{REFERENCES}

Capdevila S, Giral M, Ruiz JL, de la Torre, Russell RJ, Kramer K. Acclimatization of rats after ground transportation to a new animal facility. Laboratory Animals, 2007; 41-255.

CCRUM. 2008. National formulary of Unani Medicine, CCRUM, New Delhi Part $5^{\text {th }}$

Curry SH, Decory HH, Gabrielsson J. 2011. Phase I: the first opportunity for extrapolation from animal data to human exposure. In: Edwards LD, Fox AW, Stonier PD, eds. Principles and practise of pharmaceutical medicine. $3^{\text {rd }}$ ed. West Succex: Wiley Blackwell. 85-98.
Hkm AH. 2005. Sanatul Tahlees, CCRUM, New Delhi, pp. 207. Kabeer-u-din M and Bayaaz Kabir. 2011. Hikmat Book Depot, Hyderabad, vol. 1, pp. 114

Hilaly JE, Israili ZH, Lyouss B. Acute and chronic toxicological studies of Ajuva Iva in experimental animals. Journal of Ethnopharmacology, 2004; 91: 43-50.

Nandy S. and Datta R. Acute and subacute toxicity studies of methanolic leaves extract of Pterospermum acerifolium $\mathrm{L}$ wild in rodents. Int. J. Pharm. Life. Sci, 2012; 3(3): 1519-1529.

OECD. 1998. Test no. 408, OECD Guidelines for testing of chemicals. Repeated dose 90 days oral toxicity study in Rodents. OECD Publishing.

Qarabadeen J. 2005. CCRUM, New Delhi, pp. 177.

Shobha K, Zubair A. Ramabhimaiaha S, Prabhakar P. AntiInflammatory Activity of Raphanus sativus L in Acute and Chronic Experimental Models in Albino Rats. Biomedical \& Pharmacology Journal. 2013; 6(2): 315-320

Sireetawong S, Lertprasertsuke N, Srisawat U, Thuppia A, Ngaamjariyawat A, Suwannlihio N, Jaijoy K. Acute and sub-chronic toxicity study of the water extract from Tiliacoratrianora Diels in rats. Journal of Science and Technology. 2008; 30: 729-737.

\section{How to cite this article:}

Dar S, Akbar S, Ghazanfar K, Hamdani M, Nazir T, Mir MS, Masood A, Rafiq H, Ganie SA. Sub-chronic oral toxicity study of Kushta Hajrul-Yahood (A Herbo-mineral Unani formulation) in Wistar rats. J App Pharm Sci, 2016; 6 (11): 105-113. 